\title{
Molecular Mechanisms Influencing Bacterial Conjugation in the Intestinal Microbiota
}

\author{
Kevin Neilt, Nancy Allardt and Sébastien Rodrigue* \\ Départment de Biologie, Université de Sherbrooke, Sherbrooke, QC, Canada
}

Bacterial conjugation is a widespread and particularly efficient strategy to horizontally disseminate genes in microbial populations. With a rich and dense population of microorganisms, the intestinal microbiota is often considered a fertile environment for conjugative transfer and a major reservoir of antibiotic resistance genes. In this minireview, we summarize recent findings suggesting that few conjugative plasmid families

OPEN ACCESS

Edited by:

Sheng Chen,

City University of Hong Kong,

Hong Kong

Reviewed by:

Christopher Morton Thomas,

University of Birmingham,

United Kingdom

Masaki Shintani,

Shizuoka University, Japan

*Correspondence:

Sébastien Rodrigue

Sebastien.Rodrigue@USherbrooke.ca

tThese authors have contributed equally to this work and share first

authorship

Specialty section:

This article was submitted to Antimicrobials, Resistance and Chemotherapy,

a section of the journal Frontiers in Microbiology

Received: 27 February 2021 Accepted: 10 May 2021

Published: 04 June 2021

Citation:

Neil K, Allard N and Rodrigue $S$

(2021) Molecular Mechanisms Influencing Bacterial Conjugation

in the Intestinal Microbiota.

Front. Microbiol. 12:673260.

doi: 10.3389/fmicb.2021.673260 present in Enterobacteriaceae transfer at high rates in the gut microbiota. We discuss the importance of mating pair stabilization as well as additional factors influencing DNA transfer efficiency and conjugative host range in this environment. Finally, we examine the potential repurposing of bacterial conjugation for microbiome editing.

Keywords: bacterial conjugation, microbiota, conjugative plasmids (CP), mating pair stabilization, antibiotic resistance

\section{INTRODUCTION}

Antimicrobial resistance continues to rise worldwide, with alarming projections suggesting that antibiotic-resistant infections could become the second most common cause of death by 2050 (O' Neil, 2014). This led many research groups to study the global collection of antibiotic resistance genes, also called the resistome (Carattoli, 2013; Penders et al., 2013; van Schaik, 2015; CasalsPascual et al., 2018), and to identify the intestinal microbiota as a major reservoir of antibiotic resistance genes (Ravi et al., 2014). The complex microbial communities found in the gut are dense and composed of diverse bacteria phyla (Turnbaugh et al., 2007; Qin et al., 2010), a context thought to be particularly favorable for horizontal gene transfer (Liu et al., 2012; Soucy et al., 2015) and antibiotic resistance gene dissemination (San Millan, 2018). Given that the intestinal microbiota also contains a variety of pathobionts (Palleja et al., 2018; Bakkeren et al., 2019), understanding the molecular mechanisms driving the spread of antibiotic resistance genes is particularly important to prevent infections that could become difficult or impossible to treat.

Horizontal gene transfer mechanisms include transformation, transduction, and bacterial conjugation. Bacterial conjugation is considered a major contributor to gene transfer and to the emergence of new antibiotic-resistant pathogens. Conjugative transfer is a well characterized phenomenon during which a donor bacterium assembles a type IV secretion system (T4SS) and transfers DNA to a recipient bacterium in close contact (Cascales and Christie, 2003; AlvarezMartinez and Christie, 2009; Arutyunov and Frost, 2013; Virolle et al., 2020). Although thoroughly investigated in test tubes and Petri dishes, the study of bacterial conjugation in the intestinal microbiota remains far less characterized with most evidence being provided by epidemiologic studies (Norman et al., 2009; Chen et al., 2013; Soucy et al., 2015; Sun et al., 2016; San Millan, 2018). IncF, IncI, IncA, IncC, and IncH plasmids are the most frequently encountered in humans 
and animals (Rozwandowicz et al., 2018) but few studies have quantified the transmission of mobile genetic elements in situ and described the underlying mechanisms. This mini-review summarizes recent findings on bacterial conjugation in the gut microbiome with a focus on enterobacteria.

\section{THE MOBILITY OF GENES IN THE GUT MICROBIOTA}

Many studies have reported conjugative transfer of plasmids in the intestinal microbiota (Licht and Wilcks, 2005). For instance, conjugation was found to occur with plasmids of different incompatibility groups (Table 1) harbored by Gram-negative (Kasuya, 1964; Reed et al., 1969; Jones and Curtiss, 1970; DuvalIflah et al., 1980, 1994; Corpet et al., 1989; Garrigues-Jeanjean et al., 1999; Licht et al., 1999, 2003; García-Quintanilla et al., 2008; Stecher et al., 2012; Aviv et al., 2016; Gumpert et al., 2017; Bakkeren et al., 2019; Neil et al., 2020; Ott et al., 2020) or Gram-positive bacteria (Doucet-Populaire et al., 1991, 1992; McConnell et al., 1991; Schlundt et al., 1994; Igimi et al., 1996; Jacobsen et al., 1999; Moubareck et al., 2003; Lester et al., 2004). Most studies focused on Escherichia coli as the donor bacterium but lactic acid bacteria have also been investigated because of their abundance in fermented food products (Igimi et al., 1996). Despite major implications on microbial evolution and on the emergence of antibiotic-resistant pathogens, our knowledge of the molecular mechanisms facilitating bacterial conjugation in the gut microbiota remains sparse (Norman et al., 2009; Soucy et al., 2015; Casals-Pascual et al., 2018).

Several environmental conditions resembling those encountered in the intestinal tract were investigated in vitro and shown to influence conjugation (Rang et al., 1996). For example, the transfer rates of conjugative plasmids pES1 and pSLT were shown to be affected by lower oxygen levels and the presence of bile salt or by other factors such as $\mathrm{NaCl}$ concentration and temperature (García-Quintanilla et al., 2008; Aviv et al., 2016). Other plasmids were shown to be inhibited by the presence of mammalian cells in co-cultures, raising the possibility that human host secreted factors could affect plasmid transfer rates (Lim et al., 2008; Machado and Sommer, 2014). A pioneering study reported in 1999 that IncF plasmid R1drd19 can transfer between two $E$. coli strains within the mouse gut microbiome at rates similar to those obtained on agar plates (Licht et al., 1999). This led to the hypothesis that bacterial mating may occur in a stable matrix, most likely after the formation of biofilm in the gut. In situ transfer rates were also quantified directly in the mouse intestinal microbiota for other conjugative plasmids (Table 1). However, different models with several experimental variables were used. For example, different mice models ranging from germ-free to antibiotic-treated mice have been reported (Licht and Wilcks, 2005). Another important variable comes from the nature of the donor strain and recipient strains, which were shown to affect transfer rates in the gut (Ott et al., 2020). While some studies introduced and probed specific bacteria as recipient cells for conjugation, other investigations used endogenous residents of the microbiota. Furthermore, mixing donors and recipient strains before their introduction in the mice (Stecher et al., 2012) could also introduce differences since conjugation could occur between the two strains before or in the stomach immediately after their introduction in mice rather than in the intestinal microbiota. Taken together, these variations in experimental models make the comparison of transfer rates difficult between studies.

A recent study by our group adopted a standardized assay to evaluate and compare the mobility of conjugative plasmids in the mouse gut microbiota (Neil et al., 2020). Transfer rates were quantified for 13 conjugative plasmids representing 10 of the major conjugative plasmids incompatibility groups found in Enterobacteriaceae (Table 1). This work was performed in streptomycin-treated mice to deplete endogenous enterobacteria and facilitate the establishment of E. coli Nissle, 1917 derivatives as the donor and recipient bacteria. This work revealed that few conjugative plasmids were able to efficiently transfer in situ using this model, without any correlation with in vitro conjugation rates. A surprising finding was that incompatibility group $\mathrm{I}_{2}\left(\mathrm{IncI}_{2}\right)$ plasmid TP114 displayed only modest conjugation efficiencies in vitro but reached very high transfer rates in the intestinal microbiota, which prompted a more thorough investigation of this plasmid. A first observation was that hypoxic conditions increased the relatively modest TP114 in vitro transfer rates to very high frequencies of conjugation in situ. Transposon mutagenesis coupled to conjugation experiments also highlighted the crucial role of a group of genes encoding an accessory type IVb pilus (T4P) for TP114 conjugation in the intestinal tract (Neil et al., 2020). The T4P is a structure found in I-complex plasmids (IncB/O, IncI1, IncI2, IncK, and IncZ) that was previously proposed to stabilize the mating-pair in order to allow conjugation in unstable environments (Ishiwa and Komano, 2000; Praszkier and Pittard, 2005).

\section{MATING-PAIR STABILIZATION MECHANISMS}

The T4SS is a sophisticated nanomachine that plays an essential role in the transfer of DNA and/or protein macromolecules during bacterial conjugation. An important step during this process is mating-pair formation (MPF), which brings the donor and recipient bacteria in close contact (Chandran Darbari and Waksman, 2015; Christie, 2016; Virolle et al., 2020). In enterobacteria, two basic forms of conjugative pilus are associated with T4SS, either thin flexible or thick rigid, which influences the ability to support conjugation in liquid or solid environments (Arutyunov and Frost, 2013; Chandran Darbari and Waksman, 2015; Virolle et al., 2020). Besides MPF, a generally overlooked step called mating-pair stabilization (MPS) may be needed to keep the donor and recipient cells together long enough to allow successful DNA transfer. MPS is especially important in broth/in vivo conditions where bacterial mobility, flow forces, and other environmental factors could perturb the interaction between the donor and recipient cells (Clarke et al., 2008; Figures 1A-C). MPS relies on adhesins either displayed at the surface of the bacterium or on specialized 


\begin{tabular}{|c|c|c|c|c|c|c|c|c|c|c|}
\hline Name & Inc group & Resistance & Isolated in & Donor strain & Recipient strain & $\begin{array}{c}\text { Transfer } \\
\text { rates+in vitro** }\end{array}$ & $\begin{array}{c}\text { Transfer } \\
\text { rates+in situ }\end{array}$ & $\begin{array}{l}\text { MPS } \\
\text { family }\end{array}$ & Genbank & References \\
\hline pAM $\beta 1$ & 18 & $\mathrm{Er}, \mathrm{Lc}$ & Enterococcus faecalis & $\begin{array}{l}\text { Lactococcus lactis } \\
\text { IL1403 }\end{array}$ & $\begin{array}{l}\text { Enterococcus faecalis } \\
\text { HS32 }\end{array}$ & $2.3 \times 10^{-3}$ & $\begin{array}{c}<1 \times 10^{-7} \\
\text { (a) }\end{array}$ & $\begin{array}{l}\text { Not } \\
\text { reported }\end{array}$ & $\begin{array}{c}\mathrm{NC}_{-} \\
013514.1\end{array}$ & $\begin{array}{l}\text { Igimi et al., } \\
1996\end{array}$ \\
\hline $\begin{array}{l}\text { pAT191 } \\
\text { (synthetic) }^{*}\end{array}$ & 18 & $\mathrm{Km}$ & Enterococcus faecalis & $\begin{array}{l}\text { Enterococcus faecalis } \\
\text { BM4110 }\end{array}$ & $\begin{array}{l}\text { Escherichia coli } \\
\text { K802N::Tn10 }\end{array}$ & $5 \times 10^{-9}$ & $3 \times 10^{-9}(a)$ & $\begin{array}{l}\text { Not } \\
\text { reported }\end{array}$ & $\begin{array}{c}\text { Not } \\
\text { deposited }\end{array}$ & $\begin{array}{l}\text { Doucet- } \\
\text { Populaire } \\
\text { et al., } 1992\end{array}$ \\
\hline pAM714 & Hly & Er & Enterococcus faecalis & $\begin{array}{l}\text { Enterococcus faecalis } \\
\text { FA2-2 }\end{array}$ & $\begin{array}{l}\text { Enterococcus faecalis } \\
\mathrm{JH} 2 \mathrm{SS}\end{array}$ & $\sim 1 \times 10^{-2}$ & $\begin{array}{c}1.4 \times 10^{-1} \\
\text { (b) }\end{array}$ & $\begin{array}{l}\text { Not } \\
\text { reported }\end{array}$ & $\begin{array}{c}\text { Not } \\
\text { deposited }\end{array}$ & $\begin{array}{l}\text { Huycke et al., } \\
1992\end{array}$ \\
\hline pAM771 & Hly & Er & Enterococcus faecalis & $\begin{array}{l}\text { Enterococcus faecalis } \\
\text { FA2-2 }\end{array}$ & $\begin{array}{l}\text { Enterococcus faecalis } \\
\mathrm{JH} 2 \mathrm{SS}\end{array}$ & Not reported & $\begin{array}{l}2.9 \times 10^{-2} \\
\text { (b) }\end{array}$ & $\begin{array}{l}\text { Not } \\
\text { reported }\end{array}$ & $\begin{array}{c}\text { Not } \\
\text { deposited }\end{array}$ & $\begin{array}{l}\text { Huycke et al., } \\
1992\end{array}$ \\
\hline pCAL1/pCAL2 & Not found & Er & Enterococcus faecium & $\begin{array}{l}\text { Enterococcus faecium } \\
160 / 00\end{array}$ & $\begin{array}{l}\text { Enterococcus faecium } \\
64 / 3 \text {-RFS }\end{array}$ & $2 \times 10^{-5}$ & $\begin{array}{l}\sim 1 \times 10^{-6} \\
\text { (a) }\end{array}$ & $\begin{array}{l}\text { Not } \\
\text { reported }\end{array}$ & $\begin{array}{c}\text { Not } \\
\text { deposited }\end{array}$ & $\begin{array}{l}\text { Lester et al., } \\
2004\end{array}$ \\
\hline pCF10 & Not found & Tc & Enterococcus faecalis & $\begin{array}{l}\text { Enterococcus faecalis } \\
\text { OG1RFS }\end{array}$ & $\begin{array}{l}\text { Enterococcus faecalis } \\
\text { OG1SS }\end{array}$ & Data not shown & $\begin{array}{c}\sim 1 \times 10^{-3} \\
\text { (c) }\end{array}$ & $\begin{array}{l}\text { Not } \\
\text { reported }\end{array}$ & $\begin{array}{c}\mathrm{NC}_{-} \\
006827.2\end{array}$ & $\begin{array}{l}\text { Licht et al., } \\
2002\end{array}$ \\
\hline $\operatorname{Tn} 1545$ & $--^{\star \star \star \star}$ & $\mathrm{Km}, \mathrm{Er}, \mathrm{Tc}$ & $\begin{array}{l}\text { Streptococcus } \\
\text { pneumoniae }\end{array}$ & $\begin{array}{l}\text { Enterococcus faecalis } \\
\text { BM4110 }\end{array}$ & $\begin{array}{l}\text { Listeria monocytogenes } \\
\text { LO17RF }\end{array}$ & $2.5 \times 10^{-7}$ & $\begin{array}{c}1.1 \times 10^{-8} \\
\text { (a) }\end{array}$ & $\begin{array}{l}\text { Not } \\
\text { reported }\end{array}$ & AM903082.1 & $\begin{array}{l}\text { Doucet- } \\
\text { Populaire } \\
\text { et al., } 1991\end{array}$ \\
\hline $\operatorname{Tn} 916$ & $-^{\star \star \star \star}$ & Tc & Bacillus subtilis & $\begin{array}{l}\text { Enterococcus faecalis } \\
\text { OG1SS }\end{array}$ & $\begin{array}{l}\text { Enterococcus faecalis } \\
\text { OG1RF }\end{array}$ & $1.1 \times 10^{-5}$ & $\begin{array}{l}\sim 1 \times 10^{-9} \\
\text { (d) }\end{array}$ & $\begin{array}{l}\text { Not } \\
\text { reported }\end{array}$ & KM516885.1 & $\begin{array}{l}\text { Bahl et al., } \\
2004\end{array}$ \\
\hline pYD1 & Not found & $\begin{array}{l}14 \text { antibiotic } \\
\text { resistance } \\
\text { markers }\end{array}$ & Serratia liquefasciens & Serratia liquefasciens & Escherichia coli & Not reported & $\begin{array}{l}\sim 1 \times 10^{-6} \\
\text { (a) }\end{array}$ & $\begin{array}{c}\text { Not } \\
\text { reported }\end{array}$ & $\begin{array}{c}\text { Not } \\
\text { deposited }\end{array}$ & $\begin{array}{l}\text { Duval-Iflah } \\
\text { et al., } 1980\end{array}$ \\
\hline ROR-1 & Not found & Tc & Not found & Escherichia coli M7-18 & Escherichia coli x820 & $\sim 1 \times 10^{-5}$ & $\begin{array}{c}\sim 1 \times 10^{-4} \\
\text { (a) }\end{array}$ & $\begin{array}{l}\text { Not } \\
\text { reported }\end{array}$ & $\begin{array}{c}\text { Not } \\
\text { deposited }\end{array}$ & $\begin{array}{l}\text { Jones and } \\
\text { Curtiss, } 1970\end{array}$ \\
\hline plP72 & $\mathrm{B} / \mathrm{O}$ & $\mathrm{Km}$ & Escherichia coli & $\begin{array}{l}\text { Escherichia coli } \\
\text { Nissle1917 }\end{array}$ & $\begin{array}{l}\text { Escherichia coli } \\
\text { Nissle1917 }\end{array}$ & $3.57 \times 10^{-4}$ & $\begin{array}{c}3.56 \times 10^{-5} \\
\text { (a) }\end{array}$ & PilV & MN612051.1 & $\begin{array}{l}\text { Neil et al., } \\
2020\end{array}$ \\
\hline $\mathrm{pVCR} 94 \Delta \mathrm{X3}$ & C & $\mathrm{Km}$ & Vibrio cholerae & $\begin{array}{l}\text { Escherichia coli } \\
\text { Nissle1917 }\end{array}$ & $\begin{array}{l}\text { Escherichia coli } \\
\text { Nissle1917 }\end{array}$ & $3.23 \times 10^{-3}$ & $\begin{array}{l}\text { Not detected } \\
\text { (a) }\end{array}$ & TraN & KF551948.1 & $\begin{array}{l}\text { Neil et al., } \\
2020\end{array}$ \\
\hline pSLT $\Delta$ finO & $\mathrm{F}$ & $\mathrm{Km}$ & $\begin{array}{l}\text { Salmonella enterica } \\
\text { subsp. enterica serovar } \\
\text { Typhimurium }\end{array}$ & $\begin{array}{l}\text { Salmonella enterica } \\
\text { subsp. enterica serovar } \\
\text { Typhimurium SV5535 }\end{array}$ & $\begin{array}{l}\text { Salmonella enterica } \\
\text { subsp. enterica serovar } \\
\text { Typhimurium SV5534 }\end{array}$ & $5 \times 10^{-4}$ & $5 \times 10^{-5}(\mathrm{a})$ & TraN & AE006471.2 & $\begin{array}{l}\text { García- } \\
\text { Quintanilla } \\
\text { et al., } 2008\end{array}$ \\
\hline pOX38 & $\mathrm{Fl}$ & $\mathrm{Sp}, \mathrm{Tc}, \mathrm{Su}$ & Escherichia coli & $\begin{array}{l}\text { Escherichia coli } \\
\text { Nissle1917 }\end{array}$ & $\begin{array}{l}\text { Escherichia coli } \\
\text { Nissle1917 }\end{array}$ & $6.82 \times 10^{-2}$ & $\begin{array}{c}4.89 \times 10^{-5} \\
\text { (a) }\end{array}$ & TraN & MF370216.1 & $\begin{array}{l}\text { Neil et al., } \\
2020\end{array}$ \\
\hline RIP71a & FII & $\begin{array}{l}\text { Ap, Tc, Cm, } \\
\text { Sm, Sp }\end{array}$ & Escherichia coli & $\begin{array}{l}\text { Escherichia coli } \\
\text { Nissle1917 }\end{array}$ & $\begin{array}{l}\text { Escherichia coli } \\
\text { Nissle1917 }\end{array}$ & $2.64 \times 10^{-3}$ & $\begin{array}{l}7.87 \times 10^{-4} \\
\text { (a) }\end{array}$ & TraN & MN626601 & $\begin{array}{l}\text { Neil et al., } \\
2020\end{array}$ \\
\hline R1 & FII & $\begin{array}{c}\mathrm{Km}, \mathrm{Cm}, \mathrm{Su}, \\
\mathrm{Sp}\end{array}$ & $\begin{array}{l}\text { Salmonella enterica } \\
\text { subsp. enterica serovar } \\
\text { Paratyphi B }\end{array}$ & $\begin{array}{l}\text { Escherichia coli } \\
\text { Nissle1917 }\end{array}$ & $\begin{array}{l}\text { Escherichia coli } \\
\text { Nissle1917 }\end{array}$ & $2.97 \times 10^{-3}$ & $\begin{array}{c}1.6 \times 10^{-4} \\
\text { (a) }\end{array}$ & TraN & KY749247.1 & $\begin{array}{l}\text { Neil et al., } \\
2020\end{array}$ \\
\hline R1drd19 & FII & $\begin{array}{l}\mathrm{Km}, \mathrm{Cm}, \mathrm{Su} \\
\mathrm{Sp}, \mathrm{Ap}\end{array}$ & $\begin{array}{l}\text { Salmonella enterica } \\
\text { subsp. enterica serovar } \\
\text { Paratyphi B }\end{array}$ & Escherichia coli BJ4 & Escherichia coli BJ4 & $\sim 1 \times 10^{-1}$ & $\begin{array}{c}\sim 1 \times 10^{-3} \\
\text { (a) }\end{array}$ & TraN & $\begin{array}{c}\text { Not } \\
\text { deposited }\end{array}$ & $\begin{array}{l}\text { Licht et al., } \\
1999\end{array}$ \\
\hline
\end{tabular}


TABLE 1 | Continued

\begin{tabular}{|c|c|c|c|c|c|c|c|c|c|c|}
\hline Name & Inc group & Resistance & Isolated in & Donor strain & Recipient strain & $\begin{array}{c}\text { Transfer } \\
\text { rates+in vitro** }\end{array}$ & $\begin{array}{l}\text { Transfer } \\
\text { rates+in situ }\end{array}$ & $\begin{array}{l}\text { MPS } \\
\text { family }\end{array}$ & Genbank & References \\
\hline pCVM29188_146 & FIIA & Sm, Tc & $\begin{array}{l}\text { Salmonella enterica } \\
\text { subsp. enterica serovar } \\
\text { Kentucky }\end{array}$ & $\begin{array}{l}\text { Salmonella enterica } \\
\text { subsp. enterica serovar } \\
\text { Kentucky }\end{array}$ & Escherichia coli HS-4 & $\sim 1 \times 10^{-4}$ & $\begin{array}{l}\sim 5 \times 10^{-4} \\
\text { (a) }\end{array}$ & TraN & СР001122.1 & $\begin{array}{l}\text { Ott et al., } \\
2020\end{array}$ \\
\hline TP123 & $\mathrm{Hl} 1$ & $\begin{array}{l}\mathrm{Sm}, \mathrm{Cm}, \mathrm{Su} \\
\mathrm{Sp}\end{array}$ & $\begin{array}{l}\text { Salmonella enterica } \\
\text { subsp. enterica serovar } \\
\text { Typhi }\end{array}$ & $\begin{array}{l}\text { Escherichia coli } \\
\text { Nissle1917 }\end{array}$ & $\begin{array}{l}\text { Escherichia coli } \\
\text { Nissle1917 }\end{array}$ & $8.05 \times 10^{-3}$ & $\begin{array}{l}\text { Not detected } \\
\text { (a) }\end{array}$ & TraN & MN626602.1 & $\begin{array}{l}\text { Neil et al., } \\
2020\end{array}$ \\
\hline R64 & $11 \alpha$ & $\mathrm{Sm}, \mathrm{Tc}$ & $\begin{array}{l}\text { Salmonella enterica } \\
\text { subsp. enterica serovar } \\
\text { Typhimurium }\end{array}$ & $\begin{array}{l}\text { Escherichia coli } \\
\text { Nissle1917 }\end{array}$ & $\begin{array}{l}\text { Escherichia coli } \\
\text { Nissle1917 }\end{array}$ & $5.51 \times 10^{-4}$ & $\begin{array}{c}1.54 \times 10^{-6} \\
\text { (a) }\end{array}$ & PilV & $\begin{array}{c}\mathrm{NC}_{-} \\
005014.1\end{array}$ & $\begin{array}{l}\text { Neil et al., } \\
2020\end{array}$ \\
\hline p2kan & 11 & $\mathrm{Km}$ & $\begin{array}{l}\text { Salmonella enterica } \\
\text { subsp. enterica serovar } \\
\text { Typhimurium }\end{array}$ & $\begin{array}{l}\text { Salmonella enterica } \\
\text { subsp. enterica serovar } \\
\text { Typhimurium SL1344 }\end{array}$ & Escherichia coli & $\begin{array}{c}7.53 \times 10^{-3} \text { to } \\
5.20 \times 10^{-9}\end{array}$ & $\sim 1 \times 10^{0}$ (a) & PilV & $\begin{array}{c}\text { Not } \\
\text { deposited }\end{array}$ & $\begin{array}{l}\text { Stecher et al., } \\
2012\end{array}$ \\
\hline pHUSEC41-1 & 11 & $\begin{array}{l}\text { Su, Ap, Sm, } \\
\text { Pip }\end{array}$ & $\begin{array}{l}\text { Escherichia coli } \\
\text { HUSEC41 }\end{array}$ & Escherichia coli & Escherichia coli & Not reported & $\begin{array}{l}\text { Not reported } \\
\text { (a) }\end{array}$ & PilV & $\begin{array}{c}\mathrm{NC}_{-} \\
018995.1\end{array}$ & $\begin{array}{l}\text { Gumpert } \\
\text { et al., } 2017\end{array}$ \\
\hline pES1 & 11 & Tc, Su, Tr & $\begin{array}{l}\text { Salmonella enterica } \\
\text { subsp. enterica serovar } \\
\text { Infantis }\end{array}$ & Escherichia coli & $\begin{array}{l}\text { Salmonella enterica } \\
\text { subsp. enterica serovar } \\
\text { Typhimurium SL1344 }\end{array}$ & $1.2 \times 10^{-6}$ & $2 \times 10^{-7}$ (a) & PilV & $\begin{array}{c}\mathrm{NZ} \\
\mathrm{CP} 047882.1\end{array}$ & $\begin{array}{l}\text { Aviv et al., } \\
2016\end{array}$ \\
\hline TP114 & 12 & $\mathrm{Km}$ & Escherichia coli & $\begin{array}{l}\text { Escherichia coli } \\
\text { Nissle1917 }\end{array}$ & $\begin{array}{l}\text { Escherichia coli } \\
\text { Nissle1917 }\end{array}$ & $7.05 \times 10^{-3}$ & $\begin{array}{c}1.12 \times 10^{-1} \\
\text { (a) }\end{array}$ & PilV & MF521836.1 & $\begin{array}{l}\text { Neil et al., } \\
2020\end{array}$ \\
\hline plP69 & $L / M$ & $\mathrm{Ap}, \mathrm{Km}, \mathrm{Tc}$ & $\begin{array}{l}\text { Salmonella enterica } \\
\text { subsp. enterica serovar } \\
\text { Paratyphi }\end{array}$ & $\begin{array}{l}\text { Escherichia coli } \\
\text { Nissle1917 }\end{array}$ & $\begin{array}{l}\text { Escherichia coli } \\
\text { Nissle1917 }\end{array}$ & $9.73 \times 10^{-7}$ & $\begin{array}{l}\text { Not detected } \\
\text { (a) }\end{array}$ & $\begin{array}{l}\text { Not } \\
\text { reported }\end{array}$ & MN626603 & $\begin{array}{l}\text { Neil et al., } \\
2020\end{array}$ \\
\hline \multirow[t]{2}{*}{ RP1/RP4 } & $\mathrm{P} 1 \alpha$ & $\mathrm{Ap}, \mathrm{Km}, \mathrm{Tc}$ & $\begin{array}{l}\text { Pseudomonas } \\
\text { aeruginosa }\end{array}$ & Escherichia coli HB101 & Escherichia coli X7 & $2.05 \times 10^{-1}$ & $\begin{array}{l}9.21 \times 10^{-5} \\
\text { (a) }\end{array}$ & None & BN000925.1 & $\begin{array}{l}\text { Rang et al., } \\
1996\end{array}$ \\
\hline & & & & Escherichia coli BJ4 & Escherichia coli BJ4 & $2.56 \times 10^{-2}$ & $\begin{array}{l}\text { Not } \\
\text { detected } \\
\text { (a) }\end{array}$ & None & BN000925.1 & $\begin{array}{l}\text { Licht et al., } \\
2003\end{array}$ \\
\hline $\begin{array}{l}\text { pRK24 (derived } \\
\text { from RK2) }\end{array}$ & & Ap, Tc & $\begin{array}{l}\text { Enterobacter } \\
\text { aerogenes }\end{array}$ & $\begin{array}{l}\text { Escherichia coli } \\
\text { Nissle1917 }\end{array}$ & $\begin{array}{l}\text { Escherichia coli } \\
\text { Nissle1917 }\end{array}$ & $4.07 \times 10^{-1}$ & $\begin{array}{l}\text { Not detected } \\
\text { (a) }\end{array}$ & None & $\begin{array}{c}\text { Not } \\
\text { deposited }\end{array}$ & $\begin{array}{l}\text { Neil et al., } \\
2020\end{array}$ \\
\hline pRts1 & T & $\mathrm{Km}, \mathrm{Sp}$ & Proteus vulgaris & $\begin{array}{l}\text { Escherichia coli } \\
\text { Nissle1917 }\end{array}$ & $\begin{array}{l}\text { Escherichia coli } \\
\text { Nissle1917 }\end{array}$ & $2.63 \times 10^{-4}$ & $\begin{array}{l}\text { Not detected } \\
\text { (a) }\end{array}$ & TraN & MN626604 & $\begin{array}{l}\text { Neil et al., } \\
2020\end{array}$ \\
\hline \multirow[t]{2}{*}{ R388 } & W & $\mathrm{Su}, \mathrm{Tm}$ & Escherichia coli & $\begin{array}{l}\text { Escherichia coli } \\
\text { Nissle1917 }\end{array}$ & $\begin{array}{l}\text { Escherichia coli } \\
\text { Nissle1917 }\end{array}$ & $3.09 \times 10^{-4}$ & $\begin{array}{l}\text { Not detected } \\
\text { (a) }\end{array}$ & None & NC_028464 & $\begin{array}{l}\text { Neil et al., } \\
2020\end{array}$ \\
\hline & & & & $\begin{array}{l}\text { Escherichia coli } \\
\text { UB1832 }\end{array}$ & Escherichia coli UB281 & $\sim 1\left(10^{0}\right)$ & $\begin{array}{l}\sim 1 \times 10^{-4} \\
\text { (a) }\end{array}$ & None & NC_028464 & $\begin{array}{l}\text { Duval-Iflah } \\
\text { et al., 1994, } \\
1998\end{array}$ \\
\hline R6K & X2 & $\mathrm{Ap}, \mathrm{Sm}$ & Escherichia coli & $\begin{array}{l}\text { Escherichia coli } \\
\text { Nissle1917 }\end{array}$ & $\begin{array}{l}\text { Escherichia coli } \\
\text { Nissle1917 }\end{array}$ & $1.21 \times 10^{-2}$ & $\begin{array}{c}2.5 \times 10^{-4} \\
\text { (a) }\end{array}$ & $\begin{array}{l}\text { Not } \\
\text { reported }\end{array}$ & LT827129.1 & $\begin{array}{l}\text { Neil et al., } \\
2020\end{array}$ \\
\hline
\end{tabular}

*Derived from pAMß1 conjugative plasmid, has pBR322 origin of replication.

${ }^{* * M e a s u r e ~ t a k e n ~ f o r ~ c o n j u g a t i o n ~ o n ~ a g a r ~ p l a t e . ~}$

***In conditions not selecting for transconjugants.

${ }^{* * *}$ Conjugative transposons integrate into the chromosome of their host, and hence, plasmid incompatibility groups do not apply.

†Transconjugants/recipients.

(a) Mice model; (b) Hamster model; (c) Pig model; (d) rat model.

MPS family is indicated as "not reported" when the exact mechanism has not been described or with "none" when experimental evidence show that this function is absent. 
A Solid support

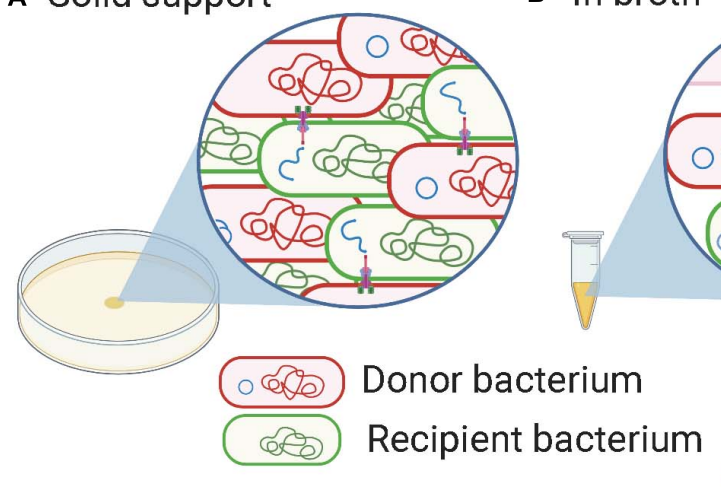

B In broth

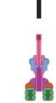

c in vivo

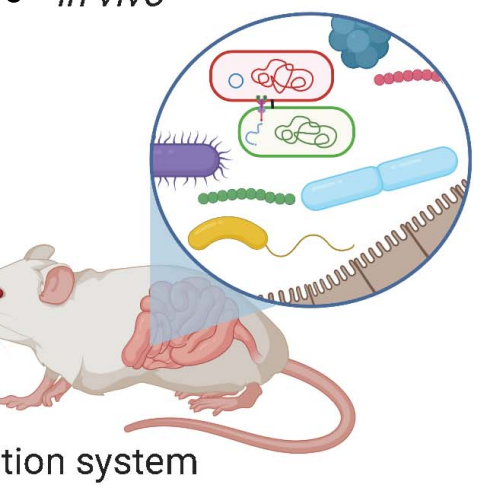

D Factors contributing to host range

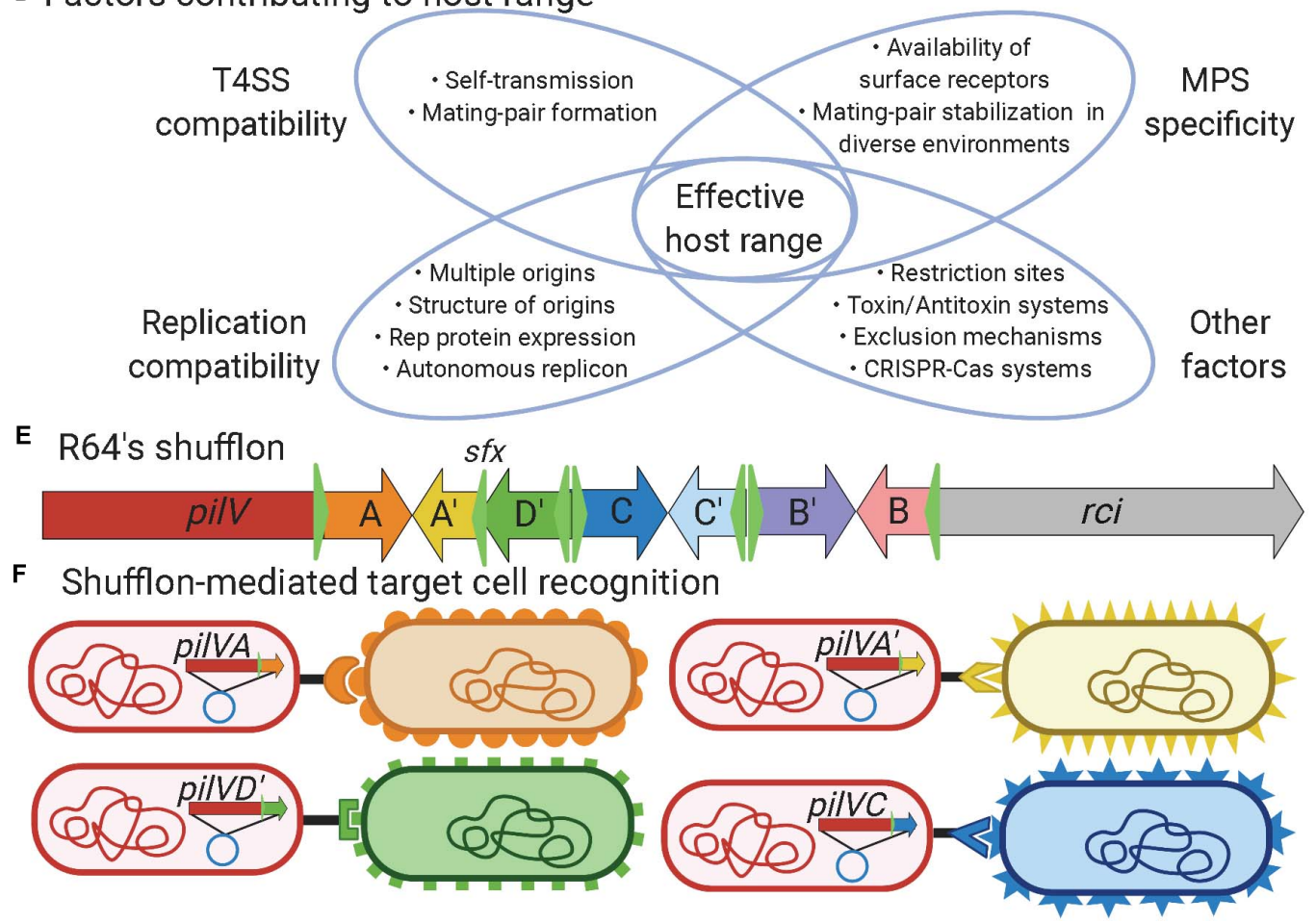

FIGURE 1 | Factors influencing bacterial conjugation. (A) Bacterial conjugation taking place on solid support provides high cell density and close proximity between donor and recipient cells that facilitate mating-pair formation to enable plasmid transfer. (B) Bacteria evolving in liquid environments or (C) in vivo benefit from mating-pair stabilization (MPS) provided either by F-pili or type IVb pili to bring cells together and keep them in close contact during plasmid transfer. (D) Venn diagram showing the factors contributing to the effective host range of a mobile genetic element. (E) Schematic representation of R64's shufflon where the C-terminus region of the pilV gene can undergo DNA rearrangement catalyzed by the shufflase (rci) to allow expression of seven variants of PilV. For example, DNA region $A$ could be exchanged to express $A^{\prime}$. (F) DNA rearrangement of the shufflon in the donor strain determines recipient specificity when mating occurred in broth/in vivo conditions. Created in BioRender.com.

pili (Hospenthal et al., 2017; González-Rivera et al., 2019). In enterobacteria, conjugative pili involved in MPS can be divided into two groups: conjugative pili and type IVb pili $(\mathrm{T} 4 \mathrm{~Pb})$ that respectively comprise the traN or pilV adhesins (Neil et al., 2020). Additional MPS mechanisms might exist, as proposed for plasmid R6K (Neil et al., 2020), since this phenomenon remains poorly characterized in most mobile genetic elements.

Different types of conjugative pilus were reported in enterobacteria (Bradley, 1980), but the most studied is probably the F-pili (Smillie et al., 2010; Arutyunov and Frost, 2013;
Koraimann, 2018). The establishment of contact between donor and recipient cells can be considered as the first rate-limiting step in conjugation as well as a key determinant for plasmid host range specificity (Virolle et al., 2020; Figure 1D). F-type pili elaborate long, thin and flexible pili that extend by polymerization of the TraA major pilin into a helical filament ranging from 1 to $20 \mu \mathrm{m}$ in length (Christie, 2016; Koraimann, 2018). Upon contact, the F-pilus retracts, presumably by depolymerization, enabling donor cells to bring the recipient cell into close proximity for the formation of the mating pore (Clarke et al., 2008; 
Hospenthal et al., 2017). TraN, also named tivF6 (Thomas et al., 2017), is an essential component for DNA transfer machinery that promotes the formation of stable donor-recipient mating-pair by interacting with OmpA or lipopolysaccharides (Klimke et al., 2005). F-pili have also been shown to promote biofilm formation, which favors plasmid transfer (Ghigo, 2001).

Type IVb pili encoded on conjugative plasmids are required only for conjugation in broth (Kim and Komano, 1997) or in the gastrointestinal tract but not on solid support (Neil et al., 2020). T4Pb are thin, flexible, helical fibers distinct from the T4SS that are mainly composed of major pilin and PilV minor adhesins that are thought to be localized to the tip of the pilus. A single motor ATPase encoding gene is predicted in $\mathrm{T} 4 \mathrm{~Pb}$, making the extension and retraction of the pilus uncertain since two ATPases are generally present in other types of T4P (Craig et al., 2019; Ellison et al., 2019). T4Pb structures can be found encoded in all plasmid families within the I-complex ( IncB/O, IncI1, IncI2, IncK, and IncZ), which were grouped based on similar morphological and serological properties of their pili (Falkow et al., 1974; Bradley, 1984; Rozwandowicz et al., 2020). The adhesin gene in I-complex plasmids is generally the last gene of the $\mathrm{T} 4 \mathrm{~Pb}$ operon and its $\mathrm{C}$-terminal portion comprises a shufflon (Figure 1E). The shufflon is a dynamic DNA locus that can be re-arranged by a shufflase, encoded by rci (recombinase for clustered inversion), thought to be constitutively active in IncI plasmids (Brouwer et al., 2019). The shufflase recognizes specific DNA sequences called $s f x$ (green triangles in Figure 1E) and promotes the recombination by inversion between two headto-head $s f x$ sites (Gyohda et al., 2002). This results in variations of the C-terminal sequence of the minor pilin PilV (Komano, 1999), thus changing the specificity of these pili to recognize different structures in lipopolysaccharides (Ishiwa and Komano, 2000) or other cell surface appendages (Figure 1F).

\section{FACTORS INFLUENCING CONJUGATION IN THE GUT MICROBIOTA}

The gut microbiota is a complex assembly of microorganisms (Lloyd-Price et al., 2016). The high density of bacteria in this environment could thus be seen as a favorable context for conjugative elements to promote their dissemination (Norman et al., 2009). However, several factors that can act at different steps of conjugative transfer can limit the host spectrum or affect the transfer rates of conjugative elements (Figure 1D). The first barrier to bacterial conjugation in the gut is the regulation of mobile genetic element transfer genes by environmental conditions (Fernandez-Lopez et al., 2014; Getino and de la Cruz, 2018). For example, plasmid TP114 was found to be active by low oxygen concentrations (Neil et al., 2020). Many conjugative plasmids respond to specific conditions that may not be found in the gut and hence cannot reach high transfer rates in this environment (García-Quintanilla et al., 2008; Aviv et al., 2016; Neil et al., 2020). In some cases, MPS could be essential or significantly increase transfer rates by establishing and stabilizing the contact between the donor and recipient bacteria (Neil et al., 2020). For this purpose, conjugative elements may use adhesins that recognize receptors at the surface of recipient bacteria (Ishiwa and Komano, 2004). However, in certain environmental niches such as in a biofilm, the role of adhesins and MPS might not be as important, allowing the T4SS to enter in contact with potentially more diverse bacterial species (Król et al., 2013). The T4SS of the conjugative element also has to penetrate the recipient bacterium cell wall and membrane. The drastically different structures of Gram-negative and Gram-positive bacteria represent a physical barrier that is likely restraining the host range of some conjugative plasmids (Domaradskii, 1985). Surface or entry exclusion represent more sophisticated mechanisms that impact conjugation (Garcillán-Barcia and De La Cruz, 2008; Arutyunov and Frost, 2013). In addition, DNA molecules that are successfully transferred must not be targeted by restriction enzymes or CRISPR-Cas systems (Wilkins, 2002; Garneau et al., 2010; Roy et al., 2020). Conjugative plasmids also have to interact with the cellular machinery of their new host to allow the expression of their genes and their maintenance. Establishing the host range of a particular conjugative element is thus a complex task that requires careful investigation of several factors (Jain and Srivastava, 2013) such as the environmental conditions, the nature of the host and recipient bacteria along with other key phenomena such as MPS, MPF, gene expression, and plasmid replication (Figure 1D).

\section{THE RELATION BETWEEN CONJUGATIVE PLASMIDS IN THE GUT}

Most in situ conjugation studies to date have used simplified models involving a single conjugative element present in the donor bacterium (Neil et al., 2020; Ott et al., 2020). This does not necessarily represent natural conditions as gut Enterobacteriaceae isolates often harbor multiple plasmids (Lyimo et al., 2016; Martino et al., 2019). Mobile genetic elements were shown to have complex relationships (Getino and de la Cruz, 2018). Some conjugative plasmids, such as IncI plasmids, encode transcription factors that inhibit IncF plasmid conjugation (Gasson and Willetts, 1975, 1976, 1977; Gaffney et al., 1983; Ham and Skurray, 1989). In other cases, the regulatory proteins from a conjugative plasmid or an integrative and conjugative element (ICE) can activate gene expression in other mobile genetic elements such as genomic islands. In an elegant study, it was also shown that some mobile genetic islands such as SGI1, encodes for T4SS subunits that can reshape the mating apparatus of IncC plasmid pVCR94 to promote SGI1 self-propagation over pVCR94 conjugation (Carraro et al., 2017). SGI1 was also found to destabilize pVCR94 maintenance mechanisms. Examples of these types of relationships are plentiful, illustrating how frequent the interaction between mobile genetic elements must be in natural environments (Harmer et al., 2016).

Some plasmids, such as the P-type systems (RP4, R388, and pKM101) lack MPS and display lower conjugation rates in unstable environments such as culture broth or the gut microbiota (Chandran Darbari and Waksman, 2015; Neil et al., 2020). For instance, IncP plasmid RP4 showed no transfer in the intestinal tract in absence of antibiotic selection for the 
transconjugants (Licht et al., 2003). However, conjugation was shown to have implications in the stability of IncP plasmid pKJK5 in the intestinal microbiota of germ-free rats (Bahl et al., 2007). Other evidence suggests that these plasmids could highjack MPS mechanisms from other conjugative elements found in the same donor cells in a parasitic manner (Gama et al., 2017). This strategy could be beneficial to some plasmids, allowing their own transfer in a stable environment while taking advantage of other plasmids MPS systems in unstable environments. Therefore, plasmids that do not encode MPS systems should not be deemed strictly incapable of transferring in the gut microbiota. Additional work will be needed to evaluate, characterize and quantify this phenomenon and could bring new insights on the mobility of genes in the gut microbiota.

\section{CONCLUSION AND APPLICATIONS OF THIS KNOWLEDGE}

Bacterial conjugation can reach high transfer rates in the gut microbiota. Direct evidence suggests that MPS plays an important role in this environment but the genes that are involved in this mechanism are not encoded in all plasmid families (Neil et al., 2020). MPS has been overlooked by many groups since it is not required in classical bacterial conjugation assays on agar plates where cells are already in close contact. Plasmids encoding MPS genes could hence be seen as the most versatile conjugation machinery since they can promote DNA transfer under a wider diversity of conditions. Conjugative elements that do not encode MPS mechanisms could exploit plasmids that possess this feature to promote their dissemination. Understanding the interactions between plasmids in the gut microbiota could thus provide important insights on the dissemination of antibiotic resistance.

Alternatives to conventional antibiotics include, among other, vaccines (Scully et al., 2015), phage therapy (Ando et al., 2015; Nobrega et al., 2015), predatory bacteria (Dwidar et al., 2012), and anti-plasmid or anti-conjugation strategies (Thomas and Nielsen, 2005; Williams and Hergenrother, 2008; Oyedemi et al., 2016; Cabezón et al., 2017; Getino and de la Cruz, 2018). Inhibiting horizontal gene transfer in the intestinal microbiota will require the identification of potential drug targets. Given that MPS appears to be important for bacterial conjugation in the gut (Neil et al., 2020), strategies to limit or abolish this function could lower the spread of antibiotic resistance (Craig et al., 2019). This

\section{REFERENCES}

Alvarez-Martinez, C. E., and Christie, P. J. (2009). Biological diversity of prokaryotic type IV secretion systems. Microbiol. Mol.Biol.Rev. 73, 775-808. doi: 10.1128/MMBR.00023-09

Ando, H., Lemire, S., Pires, D. P., and Lu, T. K. (2015). Engineering modular viral scaffolds for targeted bacterial population editing. Cell Syst. 1, 187-196. doi: $10.1016 /$ j.cels.2015.08.013

Arutyunov, D., and Frost, L. S. (2013). F conjugation: back to the beginning. Plasmid 70, 18-32. doi: 10.1016/j.plasmid.2013.03.010 type of technology could be used in conjunction with antibiotic treatments or before medical procedures to limit the risk of resistance to treatment (Buelow et al., 2017).

Increased knowledge of bacterial conjugation in situ will also be instrumental to the development of microbiome editing technologies. Using a highly effective conjugative system, genes providing benefits to their host could be transferred and integrated into the chromosome of natural residents of the microbiota, avoiding probiotic colonization resistance (Ronda et al., 2019). This DNA mobilization technology could also be used as a CRISPR-Cas delivery vehicle (Bikard et al., 2014; Citorik et al., 2014; Yosef et al., 2015; Getino and de la Cruz, 2018; Neil et al., 2019). CRISPR could be programmed to eliminate specific bacteria causing dysbiosis, antibiotic-resistant bacteria, or pathogens, providing a precision tool for microbiome editing (Bikard and Barrangou, 2017). One could also imagine that MPS could be tuned to facilitate transfer to targeted bacterial populations while leaving other microorganisms untouched by the procedure. The study of bacterial conjugation could thus provide important knowledge that could be applicable in several aspects of the fight against antibiotic resistance.

\section{AUTHOR CONTRIBUTIONS}

KN, NA, and SR contributed to the initial conceptualization of the review. KN and NA did initial literature reviews and manuscript drafting. SR contributed to the literature review and extensive manuscript editing. All authors contributed to the final proofs and approved the submitted version.

\section{FUNDING}

SR held a chercheur boursier junior 2 fellowship from the Fonds de Recherche du Québec-Santé (FRQS). KN was the recipient of a graduate research scholarship from the Fond de Recherche du Québec-Nature et Technologie (FRQNT) and from the Natural Science and Engineering Research Council of Canada (NSERC). NA was supported by a doctoral scholarship from the Université de Sherbrooke.

\section{ACKNOWLEDGMENTS}

Figure 1 was created with BioRender.com software.

Aviv, G., Rahav, G., and Gal-Mor, O. (2016). Horizontal transfer of the Salmonella enterica serovar Infantis resistance and virulence plasmid pESI to the gut microbiota of warm-blooded hosts. mBio 7, e1395-e1416. doi: 10.1128/mBio. 01395-16

Bahl, M. I., Hansen, L. H., Licht, T. R., and Sørensen, S. J. (2007). Conjugative transfer facilitates stable maintenance of IncP-1 plasmid pKJK5 in Escherichia coli cells colonizing the gastrointestinal tract of the germ-free rat. Appl. Environ. Microbiol. 73, 341-343. doi: 10.1128/AEM.01971-06

Bahl, M. I., Sørensen, S. J., Hansen, L. H., and Licht, T. R. (2004). Effect of tetracycline on transfer and establishment of the tetracycline-inducible 
conjugative transposon Tn916 in the guts of gnotobiotic rats. App. Environ. Microbiol. 70, 758-764. doi: 10.1128/AEM.70.2.758-764.2004

Bakkeren, E., Huisman, J. S., Fattinger, S. A., Hausmann, A., Furter, M., Egli, A., et al. (2019). Salmonella persisters promote the spread of antibiotic resistance plasmids in the gut. Nature 573, 276-280. doi: 10.1038/s41586-0191521-8

Bikard, D., and Barrangou, R. (2017). Using CRISPR-Cas systems as antimicrobials. Curr. Opin. Microbiol. 37, 155-160. doi: 10.1016/j.mib.2017.08.005

Bikard, D., Euler, C. W., Jiang, W., Nussenzweig, P. M., Goldberg, G. W., Duportet, X., et al. (2014). Exploiting CRISPR-Cas nucleases to produce sequence-specific antimicrobials. Nat. Biotechnol. 32, 1146-1150. doi: 10.1038/nbt.3043

Bradley, D. E. (1980). Determination of pili by conjugative bacterial drug resistance plasmids of incompatibility groups B, C, H, J, K, M, V, and X. J. Bacteriol. 141, 828-837.

Bradley, D. E. (1984). Characteristics and function of thick and thin conjugative pili determined by transfer-derepressed plasmids of incompatibility groups I1, I2, I5, B, K, Z. J. Gen. Microbiol. 130, 1489-1502.

Brouwer, M. S. M., Jurburg, S. D., Harders, F., Kant, A., Mevius, D. J., Roberts, A. P., et al. (2019). The shufflon of IncI1 plasmids is rearranged constantly during different growth conditions. Plasmid 102, 51-55. doi: 10.1016/j.plasmid.2019. 03.003

Buelow, E., Bello González, T. d. j, Fuentes, S., de Steenhuijsen Piters, W. A. A., Lahti, L., Bayjanov, J. R., et al. (2017). Comparative gut microbiota and resistome profiling of intensive care patients receiving selective digestive tract decontamination and healthy subjects. Microbiome 5:88. doi: 10.1186/s40168017-0309-z

Cabezón, E., de la Cruz, F., and Arechaga, I. (2017). Conjugation inhibitors and their potential use to prevent dissemination of antibiotic resistance genes in bacteria. Front. Microbiol. 8:2329. doi: 10.3389/fmicb.2017.02329

Carattoli, A. (2013). Plasmids and the spread of resistance. Int. J. Med. Microbiol. 303, 298-304. doi: 10.1016/j.ijmm.2013.02.001

Carraro, N., Durand, R., Rivard, N., Anquetil, C., Barrette, C., Humbert, M., et al. (2017). Salmonella genomic island 1 (SGI1) reshapes the mating apparatus of IncC conjugative plasmids to promote self-propagation. PLoS Genet. 13:e1006705. doi: 10.1371/journal.pgen.1006705

Casals-Pascual, C., Vergara, A., and Vila, J. (2018). Intestinal microbiota and antibiotic resistance: perspectives and solutions. Hum. Microbiome J. 9, 11-15. doi: 10.1016/j.humic.2018.05.002

Cascales, E., and Christie, P. J. (2003). The versatile bacterial type IV secretion systems. Nat. Rev. Microbiol. 1, 1-7. doi: 10.1038/nrmicro753.THE

Chandran Darbari, V., and Waksman, G. (2015). Structural biology of bacterial type IV secretion systems. Annu. Rev. Biochem. 84, 603-629. doi: 10.1146/ annurev-biochem-062911-102821

Chen, L., Chavda, K. D., Al Laham, N., Melano, R. G., Jacobs, M. R., Bonomo, R. A., et al. (2013). Complete nucleotide sequence of a blaKPC-harboring IncI2 plasmid and its dissemination in New Jersey and New York hospitals. Antimicrob. Agents Chemother. 57, 5019-5025. doi: 10.1128/AAC.01397-13

Christie, P. J. (2016). The mosaic type IV secretion systems. EcoSal Plus 7, 1-34. doi: 10.1128/ecosalplus.ESP-0020-2015

Citorik, R. J., Mimee, M., and Lu, T. K. (2014). Sequence-specific antimicrobials using efficiently delivered RNA-guided nucleases. Nat. Biotechnol. 32, 11411145. doi: $10.1038 /$ nbt.3011

Clarke, M., Maddera, L., Harris, R. L., and Silverman, P. M. (2008). F-pili dynamics by live-cell imaging. Proc. Natl. Acad. Sci. U.S.A. 105, 17978-17981.

Corpet, D. E., Lumeau, S., and Corpet, F. (1989). Minimum antibiotic levels for selecting a resistance plasmid in a gnotobiotic animal model. Antimicrob. Agents Chemother. 33, 535-540. doi: 10.1128/AAC.33.4.535

Craig, L., Forest, K. T., and Maier, B. (2019). Type IV pili: dynamics, biophysics and functional consequences. Nat. Rev. Microbiol. 17, 429-440. doi: 10.1038/ s41579-019-0195-4

Domaradskii, I. V. (1985). The role of surface structures of recipient cells in bacterial conjugation. Mol. Gen. Microbiol. Viruses 12, 3-11.

Doucet-Populaire, F., Trieu-Cuot, P., Andremont, A., and Courvalin, P. (1992). Conjugal transfer of plasmid DNA from Enterococcus faecalis to Escherichia coli in digestive tracts of gnotobiotic mice. Antimicrob. Agents Chemother. 36, 502-504. doi: 10.1128/AAC.36.2.502

Doucet-Populaire, F., Trieu-Cuot, P., Dosbaa, I., Andremont, A., and Courvalin, P. (1991). Inducible transfer of conjugative transposon Tn1545 from Enterococcus faecalis to Listeria monocytogenes in the digestive tracts of gnotobiotic mice. Antimicrob. Agents Chemother. 35, 185-187. doi: 10.1128/AAC.35.1.185

Duval-Iflah, Y., Gainche, I., Ouriet, M. F., and Lett, M. C. (1994). Recombinant DNA transfer to Escherichia coli of human faecal origin in vitro and in digestive tract of gnotobiotic mice. FEMS Microbiol. Ecol. 15, 79-87. doi: 10.1111/j.15746941.1994.tb00232.x

Duval-Iflah, Y., Maisonneuve, S., and Ouriet, M. F. (1998). Effect of fermented milk intake on plasmid transfer and on the persistence of transconjugants in the digestive tract of gnotobiotic mice. Int. J. Gen. Mol. Microbiol. 73, 95-102. doi: 10.1023/A:1000603828184

Duval-Iflah, Y., Raibaud, P., Tancrede, C., and Rousseau, M. (1980). R-plasmid transfer from Serratia liquefaciens to Escherichia coli in vitro and in vivo in the digestive tract of gnotobiotic mice associated with human fecal flora. Infect. Immun. 28, 981-990.

Dwidar, M., Monnappa, A. K., and Mitchell, R. J. (2012). The dual probiotic and antibiotic nature of Bdellovibrio bacteriovorus. BMB Rep. 45, 71-78. doi: 10.5483/BMBRep.2012.45.2.71

Ellison, C. K., Kan, J., Chlebek, J. L., Hummels, K. R., Panis, G., Viollier, P. H., et al. (2019). A bifunctional ATPase drives Tad pilus extension and retraction. Sci. Adv. 5:eaay2591. doi: 10.1126/sciadv.aay2591

Falkow, S., Guerry, P., Hedges, R. W., and Datta, N. (1974). Polynucleotide sequence relationships among plasmids of the I compatibility complex. J. Gen. Microbiol. 85, 65-76. doi: 10.1128/jb.107.1.372-374.1971

Fernandez-Lopez, R., del Campo, I., Revilla, C., Cuevas, A., and de la Cruz, F. (2014). Negative feedback and transcriptional overshooting in a regulatory network for horizontal gene transfer. PLoS Genet. 10:e1004171. doi: 10.1371/ journal.pgen.1004171

Gaffney, D., Skurray, R., Willetts, N., and Brenner, S. (1983). Regulation of the F conjugation genes studied by hybridization and tra-lacZ fusion. J. Mol. Biol. 168, 103-122. doi: 10.1016/S0022-2836(83)80325-8

Gama, J. A., Zilhão, R., and Dionisio, F. (2017). Conjugation efficiency depends on intra and intercellular interactions between distinct plasmids: plasmids promote the immigration of other plasmids but repress co-colonizing plasmids. Plasmid 93, 6-16. doi: 10.1016/j.plasmid.2017.08.003

García-Quintanilla, M., Ramos-Morales, F., and Casadesús, J. (2008). Conjugal transfer of the Salmonella enterica virulence plasmid in the mouse intestine. J. Bacteriol. 190, 1922-1927. doi: 10.1128/JB.01626-07

Garcillán-Barcia, M. P., and De La Cruz, F. (2008). Why is entry exclusion an essential feature of conjugative plasmids? Plasmid 60, 1-18. doi: 10.1016/j. plasmid.2008.03.002

Garneau, J. E., Dupuis, M. Ė, Villion, M., Romero, D. A., Barrangou, R., Boyaval, P., et al. (2010). The CRISPR/cas bacterial immune system cleaves bacteriophage and plasmid DNA. Nature 468, 67-71. doi: 10.1038/nature09523

Garrigues-Jeanjean, N., Wittmer, A., Ouriet, M. F., and Duval-Iflah, Y. (1999). Transfer of the shuttle vector pRRI207 between Escherichia coli and Bacteroides spp. in vitro and in vivo in the digestive tract of axenic mice and in gnotoxenic mice inoculated with a human microflora. FEMS Microbiol. Ecol. 29, 33-43.

Gasson, M. J., and Willetts, N. S. (1975). Five control systems preventing transfer of Escherichia coli K 12 sex factor F. J. Bacteriol. 122, 518-525. doi: 10.1128/jb. 122.2.518-525.1975

Gasson, M. J., and Willetts, N. S. (1976). Transfer gene expression during fertility inhibition of the Escherichia coli K12 sex factor by the I-like plasmid R62. Mol. Gen. Genet. 149, 329-333. doi: 10.1007/BF00268535

Gasson, M. J., and Willetts, N. S. (1977). Further characterization of the F fertility inhibition systems of "unusual" Fin+ plasmids. J. Bacteriol. 131, 413-420. doi: 10.1128/jb.131.2.413-420.1977

Getino, M., and de la Cruz, F. (2018). Natural and artificial strategies to control the conjugative transmission of plasmids. Microbiol. Spectr. 6, 33-64. doi: 10.1128/ microbiolspec.mtbp-0015-2016

Ghigo, J. M. (2001). Natural conjugative plasmids induce bacterial biofilm development. Nature 412, 442-445. doi: 10.1038/35086581

González-Rivera, C., Khara, P., Awad, D., Patel, R., Li, Y. G., Bogisch, M., et al. (2019). Two pKM101-encoded proteins, the pilus-tip protein TraC and Pep, assemble on the Escherichia coli cell surface as adhesins required for efficient conjugative DNA transfer. Mol. Microbiol. 111, 96-117. doi: 10.1111/mmi. 14141

Gumpert, H., Kubicek-Sutherland, J. Z., Porse, A., Karami, N., Munck, C., Linkevicius, M., et al. (2017). Transfer and persistence of a multi-drug resistance 
plasmid in situ of the infant gut microbiota in the absence of antibiotic treatment. Front. Microbiol. 8:1852. doi: 10.3389/fmicb.2017.01852

Gyohda, A., Furuya, N., Kogure, N., and Komano, T. (2002). Sequence-specific and non-specific binding of the Rci protein to the asymmetric recombination sites of the R64 shufflon. J. Mol. Biol. 318, 975-983. doi: 10.1016/S0022-2836(02) 00195-X

Ham, L. M., and Skurray, R. (1989). Molecular analysis and nucleotide sequence of finQ, a transcriptional inhibitor of the F plasmid transfer genes. Mol. Gen. Genet. 216, 99-105. doi: 10.1007/BF00332236

Harmer, C. J., Hamidian, M., Ambrose, S. J., and Hall, R. M. (2016). Destabilization of IncA and IncC plasmids by SGI1 and SGI2 type Salmonella genomic islands. Plasmid 8, 51-57. doi: 10.1016/j.plasmid.2016.09.003

Hospenthal, M. K., Costa, T. R. D., and Waksman, G. (2017). A comprehensive guide to pilus biogenesis in Gram-negative bacteria. Nat. Rev. Microbiol. 15, 365-379. doi: 10.1038/nrmicro.2017.40

Huycke, M. M., Gilmore, M. S., Jett, B. D., and Booth, J. L. (1992). Transfer of pheromone-inducible plasmid between Enterococcus faecalis in the Syrian hamster gastrointestinal tract. J. Infect. Dis. 166, 1188-1191. doi: 10.1093/infdis/ 166.5.1188

Igimi, S., Ryu, C. H., Park, S. H., Sasaki, Y., Sasaki, T., and Kumagai, S. (1996). Transfer of conjugative plasmid pAM $\beta 1$ from Lactococcus lactis to mouse intestinal bacteria. Lett. Appl. Microbiol. 23, 31-35.

Ishiwa, A., and Komano, T. (2000). The lipopolysaccharide of recipient cells is a specific receptor for PilV proteins, selected by shufflon DNA rearrangement, in liquid matings with donors bearing the R64 plasmid. Mol. Gen. Genet. 263, 159-164. doi: 10.1007/s004380050043

Ishiwa, A., and Komano, T. (2004). PilV adhesins of plasmid R64 thin pili specifically bind to the lipopolysaccharides of recipient cells. J. Mol. Biol. 343, 615-625. doi: 10.1016/j.jmb.2004.08.059

Jacobsen, B. L., Skou, M., Hammerum, A. M., and Jensen, L. B. (1999). Horizontal transfer of the satA gene encoding streptogramin a resistance between isogenic Enterococcus faecium strains in the gastrointestinal tract of gnotobiotic rats. Microbial Ecol. Health Dis. 11, 241-247. doi: 10.1080/08910609908540834

Jain, A., and Srivastava, P. (2013). Broad host range plasmids. FEMS Microbiol. Lett. 348, 87-96. doi: 10.1111/1574-6968.12241

Jones, R. T., and Curtiss, R. (1970). Genetic exchange between Escherichia coli strains in the mouse intestine. J. Bacteriol. 103, 71-80.

Kasuya, M. (1964). Transfer of drug resistance between enteric bacteria induced in the mouse intestine. J. Bacteriol. 88, 322-328. doi: 10.1128/JB.88.2.322-328. 1964

Kim, S. R., and Komano, T. (1997). The plasmid R64 thin pilus identified as a type IV pilus. J. Bacteriol. 179, 3594-3603. doi: 10.1128/jb.179.11.3594-3603.1997

Klimke, W. A., Rypien, C. D., Klinger, B., Kennedy, R. A., Rodriguez-Maillard, J. M., and Frost, L. S. (2005). The mating pair stabilization protein, TraN, of the F plasmid is an outer-membrane protein with two regions that are important for its function in conjugation. Microbiol. 151, 3527-3540. doi: 10.1099/mic.0. 28025-0

Komano, T. (1999). Shufflons: multiple inversion systems and integrons. Annu. Rev. Genet. 33, 171-191. doi: 10.1146/annurev.genet.33.1.171

Koraimann, G. (2018). Spread and persistence of virulence and antibiotic resistance genes: a ride on the F plasmid conjugation module. EcoSal Plus 8, 1-23. doi: 10.1128/ecosalplus.esp-0003-2018

Król, J. E., Wojtowicz, A. J., Rogers, L. M., Heuer, H., Smalla, K., Krone, S. M., et al. (2013). Invasion of E. coli biofilms by antibiotic resistance plasmids. Plasmid 70, 110-119. doi: 10.1016/j.plasmid.2013.03.003

Lester, C. H., Frimodt-Moller, N., and Hammerum, A. M. (2004). Conjugal transfer of aminoglycoside and macrolide resistance between Enterococcus faecium isolates in the intestine of streptomycin-treated mice. FEMS Microbiol. Lett. 235, 385-391. doi: 10.1016/j.femsle.2004.04.050

Licht, T. R., and Wilcks, A. (2005). Conjugative gene transfer in the gastrointestinal environment. Advan. Appl. Microbiol. 58, 77-95. doi: 10.1016/S0065-2164(05) 58002-X

Licht, T. R., Christensen, B. B., Krogfelt, K. A., and Molin, S. (1999). Plasmid transfer in the animal intestine and other dynamic bacterial populations: the role of community structure and environment. Microbiol. 145, 2615-2622. doi: 10.1099/00221287-145-9-2615

Licht, T. R., Laugesen, D., Jensen, L. B., and Jacobsen, B. L. (2002). Transfer of the pheromone-inducible plasmid pCF10 among Enterococcus faecalis microorganisms colonizing the intestine of mini-pigs. Appl. Environ. Microbiol. 68, 187-193. doi: 10.1128/AEM.68.1.187-193.2002

Licht, T. R., Struve, C., Christensen, B. B., Poulsen, R. L., Molin, S., and Krogfelt, K. A. (2003). Evidence of increased spread and establishment of plasmid RP4 in the intestine under sub-inhibitory tetracycline concentrations. FEMS Microbiol. Ecol. 44, 217-223. doi: 10.1016/S0168-6496(03)00016-3

Lim, Y. M., de Groof, A. J. C., Bhattacharjee, M. K., Figurski, D. H., and Schon, E. A. (2008). Bacterial conjugation in the cytoplasm of mouse cells. Infect. Immun. 76, 5110-5119. doi: 10.1128/IAI.00445-08

Liu, L., Chen, X., Skogerbø, G., Zhang, P., Chen, R., He, S., et al. (2012). The human microbiome: a hot spot of microbial horizontal gene transfer. Genomics 100, 265-270. doi: 10.1016/j.ygeno.2012.07.012

Lloyd-Price, J., Abu-Ali, G., and Huttenhower, C. (2016). The healthy human microbiome. Genome Med. 8:51. doi: 10.1186/s13073-016-0307-y

Lyimo, B., Buza, J., Subbiah, M., Temba, S., Kipasika, H., Smith, W., et al. (2016). IncF plasmids are commonly carried by antibiotic resistant Escherichia coli isolated from drinking water sources in northern Tanzania. Int. J. Microbiol. 2016:3103672. doi: 10.1155/2016/3103672

Machado, A. M. D., and Sommer, M. O. A. (2014). Human intestinal cells modulate conjugational transfer of multidrug resistance plasmids between clinical Escherichia coli isolates. PLoS One 9:e100739. doi: 10.1371/journal.pone. 0100739

Martino, F., Tijet, N., Melano, R., Petroni, A., Heinz, E., De Belder, D., et al. (2019). Isolation of five Enterobacteriaceae species harbouring blaNDM-1 and mcr-1 plasmids from a single pediatric patient. PLoS One 14:e0221960. doi: 10.1371/journal.pone.0221960

McConnell, M. A., Mercer, A. A., and Tannock, G. W. (1991). Transfer of plasmid pAM $\beta 1$ between members of the normal microflora inhabiting the murine digestive tract and modification of the plasmid in a Lactobacillus reuteri host. Microbial. Ecol. Health Dis. 4, 343-355. doi: 10.3109/08910609109140149

Moubareck, C., Bourgeois, N., Courvalin, P., and Doucet-Populaire, F. (2003). Multiple antibiotic resistance gene transfer from animal to human enterococci in the digestive tract of gnotobiotic mice. Antimicrob. Agents Chemother. 47, 2993-2996. doi: 10.1128/AAC.47.9.2993-2996.2003

Neil, K., Allard, N., Grenier, F., Burrus, V., and Rodrigue, S. (2020). Highly efficient gene transfer in the mouse gut microbiota is enabled by the Incl 2 conjugative plasmid TP114. Commun. Biol. 3:523. doi: 10.1038/s42003-020-01253-0

Neil, K., Allard, N., Jordan, D., and Rodrigue, S. (2019). Assembly of large mobilizable genetic cargo by Double Recombinase Operated Insertion of DNA (DROID). Plasmid 104:102419. doi: 10.1016/j.plasmid.2019.102419

Nobrega, F. L., Costa, A. R., Kluskens, L. D., and Azeredo, J. (2015). Revisiting phage therapy: new applications for old resources. Trends Microbiol. 23, 185191. doi: 10.1016/j.tim.2015.01.006

Norman, A., Hansen, L. H., and Sørensen, S. J. (2009). Conjugative plasmids: vessels of the communal gene pool. Phil. Trans. R. Soc.B Biol. Sci. 364, 22752289. doi: 10.1098/rstb.2009.0037

O' Neil, J. (2014). Antimicrobial Resistance?: Tackling a Crisis for the Health and Wealth of Nations. In Rev. Antimicrob. Resist. Available online at: https://amrreview.org/sites/default/files/AMR\%20Review\%20Paper\%20\% 20Tackling\%20a $\% 20$ crisis $\% 20$ for $\% 20$ the $\% 20$ health $\% 20$ and $\% 20$ wealth $\% 20$ of $\%$ 20nations_1.pdf (accessed 28 January 2021).

Ott, L. C., Stromberg, Z. R., Redweik, G. A. J., Wannemuehler, M. J., and Mellata, M. (2020). Mouse genetic background affects transfer of an antibiotic resistance plasmid in the gastrointestinal tract. MSphere 5:e847-19. doi: 10.1128/msphere. 00847-19

Oyedemi, B. O. M., Shinde, V., Shinde, K., Kakalou, D., Stapleton, P. D., and Gibbons, S. (2016). Novel R-plasmid conjugal transfer inhibitory and antibacterial activities of phenolic compounds from Mallotus philippensis (Lam.) Mull. Arg. J. Glob. Antimicrobial Resis. 5, 15-21. doi: 10.1016/j.jgar.2016. 01.011

Palleja, A., Mikkelsen, K. H., Forslund, S. K., Kashani, A., Allin, K. H., Nielsen, T., et al. (2018). Recovery of gut microbiota of healthy adults following antibiotic exposure. Nat. Microbiol. 3, 1255-1265. doi: 10.1038/s41564-018-0257-9

Penders, J., Stobberingh, E. E., Savelkoul, P. H. M., and Wolffs, P. F. G. (2013). The human microbiome as a reservoir of antimicrobial resistance. Front. Microbiol. 4:87. doi: 10.3389/fmicb.2013.00087

Praszkier, J., and Pittard, A. J. (2005). Control of replication in I-complex plasmids. Plasmid 53, 97-112. doi: 10.1016/j.plasmid.2004.12.005 
Qin, J., Li, R., Raes, J., Arumugam, M., Burgdorf, K. S., Manichanh, C., et al. (2010). A human gut microbial gene catalog established by metagenomic sequencing. Nature 464, 59-65. doi: 10.1038/nature08821

Rang, C. U., Kennan, R. M., Midtvedt, T., Chao, L., and Conway, P. L. (1996). Transfer of the plasmid RP1 in vivo in germ free mice and in vitro in gut extracts and laboratory media. FEMS Microbiol. Ecol. 19, 133-140. doi: 10.1016/01686496(95)00087-9

Ravi, A., Avershina, E., Ludvigsen, J., L'Abée-Lund, T. M., and Rudi, K. (2014). Integrons in the intestinal microbiota as reservoirs for transmission of antibiotic resistance genes. Pathogens 3, 238-248. doi: 10.3390/pathogens3020238

Reed, N. D., Sieckmann, D. G., and Georgi, C. E. (1969). Transfer of infectious drug resistance in microbially defined mice. J. Bacteriol. 100, 22-26. doi: 10.1128/jb. 100.1.22-26.1969

Ronda, C., Chen, S. P., Cabral, V., Yaung, S. J., and Wang, H. H. (2019). Metagenomic engineering of the mammalian gut microbiome in situ. Nat. Methods 16, 167-170. doi: 10.1038/s41592-018-0301-y

Roy, D., Huguet, K. T., Grenier, F., and Burrus, V. (2020). IncC conjugative plasmids and SXT/R391 elements repair double-strand breaks caused by CRISPR-Cas during conjugation. Nucl. Acids Res. 48, 8815-8827. doi: 10.1093/ nar/gkaa518

Rozwandowicz, M., Brouwer, M. S. M., Fischer, J., Wagenaar, J. A., Gonzalez-Zorn, B., Guerra, B., et al. (2018). Plasmids carrying antimicrobial resistance genes in Enterobacteriaceae. J. Antimicrob. Chemother. 73, 1121-1137. doi: 10.1093/jac/ dkx488

Rozwandowicz, M., Hordijk, J., Bossers, A., Zomer, A. L., Wagenaar, J. A., Mevius, D. J., et al. (2020). Incompatibility and phylogenetic relationship of I-complex plasmids. Plasmid 109:102502. doi: 10.1016/j.plasmid.2020.102502

San Millan, A. (2018). Evolution of plasmid-mediated antibiotic resistance in the clinical context. Trends Microbiol. 26, 978-985. doi: 10.1016/j.tim.2018. 06.007

Schlundt, J., Saadbye, P., Lohmann, B., Jacobsen, B. L., and Nielsen, E. M. (1994). Conjugal transfer of plasmid DNA between Lactococcus lactis strains and distribution of transconjugants in the digestive tract of gnotobiotic rats. Microbial Ecol. Health Dis. 7, 59-69. doi: 10.3109/08910609409141574

Scully, I. L., Swanson, K., Green, L., Jansen, K. U., and Anderson, A. S. (2015). Antiinfective vaccination in the 21 st century-new horizons for personal and public health. Curr. Opin. Microbiol. 27, 96-102. doi: 10.1016/j.mib.2015.07.006

Smillie, C., Garcillán-Barcia, M. P., Francia, M. V., Rocha, E. P. C., and de la Cruz, F. (2010). Mobility of plasmids. Microbiol. Mol. Biol. Rev. 74, 434-452. doi: $10.1128 / \mathrm{mmbr} .00020-10$

Soucy, S. M., Huang, J., and Gogarten, J. P. (2015). Horizontal gene transfer: building the web of life. Nat. Rev. Genet. 16, 472-482. doi: 10.1038/nrg3962
Stecher, B., Denzler, R., Maier, L., Bernet, F., Sanders, M. J., Pickard, D. J., et al. (2012). Gut inflammation can boost horizontal gene transfer between pathogenic and commensal Enterobacteriaceae. Proc. Natl. Acad. Sci. U.S.A. 109, 1269-1274. doi: 10.1073/pnas.1113246109

Sun, J., Li, X. P., Yang, R. S., Fang, L. X., Huo, W., Li, S. M., et al. (2016). Complete nucleotide sequence of an IncI2 plasmid co-harboring blaCTX-M-55 and mcr-1. Antimicrob. Agents Chemother. 60, 5014-5017. doi: 10.1128/AAC.007 74-16

Thomas, C. M., and Nielsen, K. M. (2005). Mechanisms of, and barriers to, horizontal gene transfer between bacteria. Nat. Rev. Microbiol. 3, 711-721. doi: $10.1038 /$ nrmicro 1234

Thomas, C. M., Thomson, N. R., Cerdeño-Tárraga, A. M., Brown, C. J., Top, E. M., and Frost, L. S. (2017). Annotation of plasmid genes. Plasmid 91, 61-67. doi: 10.1016/j.plasmid.2017.03.006

Turnbaugh, P. J., Ley, R. E., Hamady, M., Fraser-Liggett, C. M., Knight, R., and Gordon, J. I. (2007). The human microbiome project. Nature 449, 804-810. doi: $10.1038 /$ nature 06244

van Schaik, W. (2015). The human gut resistome. Philos. Trans. R. Soc. Lond. Ser. B 370:20140087. doi: 10.1098/rstb.2014.0087

Virolle, C., Goldlust, K., Djermoun, S., Bigot, S., and Lesterlin, C. (2020). Plasmid transfer by conjugation in Gram-negative bacteria: from the cellular to the community level. Genes 11:1239. doi: 10.3390/genes11111239

Wilkins, B. M. (2002). Plasmid promiscuity: meeting the challenge of DNA immigration control. Environ. Microbiol. 4, 495-500. doi: 10.1046/j.1462-2920. 2002.00332.x

Williams, J. J., and Hergenrother, P. J. (2008). Exposing plasmids as the Achilles' heel of drug-resistant bacteria. Curr. Opin. Chem. Biol. 12, 389-399. doi: 10. 1016/j.cbpa.2008.06.015.Exposing

Yosef, I., Manor, M., Kiro, R., and Qimron, U. (2015). Temperate and lytic bacteriophages programmed to sensitize and kill antibiotic-resistant bacteria. Proc. Natl. Acad. Sci. U.S.A. 112, 7267-7272. doi: 10.1073/pnas.1500107112

Conflict of Interest: The authors have filed a patent application for the use of conjugative plasmids for microbiome editing. KN and SR are co-founders of TATUM bioscience.

Copyright (c) 2021 Neil, Allard and Rodrigue. This is an open-access article distributed under the terms of the Creative Commons Attribution License (CC BY). The use, distribution or reproduction in other forums is permitted, provided the original author(s) and the copyright owner(s) are credited and that the original publication in this journal is cited, in accordance with accepted academic practice. No use, distribution or reproduction is permitted which does not comply with these terms. 